\title{
Finding a suitable catalyst for on-board ethanol reforming using exhaust heat from an internal combustion engine
}

\author{
Albert Casanovas ${ }^{a}$, Núria J. Divins ${ }^{a}$, Alberto Rejas $^{a}$, Ricard Bosch ${ }^{b}$, \\ Jordi Llorca ${ }^{a \text {,* }}$ \\ ${ }^{a}$ Institute of Energy Technologies and Centre for Research in Nanoengineering, Universitat Politècnica de Catalunya, \\ EEBE, Barcelona, Spain \\ ${ }^{\mathrm{b}}$ Department of Electric Engineering, Universitat Politècnica de Catalunya, ETSEIB, Barcelona, Spain
}

\section{A R T I C L E I N F O}

\section{Article history:}

Received 30 September 2016

Received in revised form

30 November 2016

Accepted 30 November 2016

Available online $\mathrm{xxx}$

Keywords:

Exhaust heat

Internal combustion engine

Hydrogen

Ethanol reforming

Bioethanol

\begin{abstract}
A B S T R A C T
Ethanol steam reforming with pure ethanol and commercial bioethanol $(\mathrm{S} / \mathrm{C}=3)$ was carried out inside the housing of the exhaust gas pipe of a gasoline internal combustion engine (ICE) by using exhaust heat $\left(610-620^{\circ} \mathrm{C}\right)$. Various catalytic honeycombs loaded with potassium-promoted cobalt hydrotalcite and with ceria-based rhodium-palladium catalysts were tested under different reactant loads. The hydrogen yield obtained over the cobalt-based catalytic honeycomb at low load (F/W $<25 \mathrm{~mL}_{\text {liq }} \cdot \mathrm{g}_{\text {cat }}^{-1} \cdot \mathrm{h}^{-1}, \mathrm{GHSV}=4 \cdot 10^{2} \mathrm{~h}^{-1}$ ) was remarkably high, whereas that obtained over the noble metal-based catalytic honeycombs was much superior at high loads $\left(\mathrm{F} / \mathrm{W}=25-150 \mathrm{~mL}_{\text {liq }} \cdot \mathrm{g}_{\text {cat }}^{-1} \cdot \mathrm{h}^{-1}, \mathrm{GHSV}=4 \cdot 10^{2}\right.$ $-2.4 \cdot 10^{3} \mathrm{~h}^{-1}$ ). At higher reactant loads the overall hydrogen production was limited by heat transfer from the exhaust heat to the reformer inside the housing of the exhaust gas pipe of the ICE. Extensive carbon deposition occurred over the cobalt-based honeycomb, making its use impractical. In contrast, stability runs $(>200 \mathrm{~h})$ at high load $\left(\mathrm{F} / \mathrm{W}=150 \mathrm{~mL}\right.$ liq $\cdot \mathrm{g}_{\text {cat }}^{-1} \cdot \mathrm{h}^{-1}$, GHSV $=2.4 \cdot 10^{3} \mathrm{~h}^{-1}$ ) showed that promotion of the ceria-supported noble metal catalyst with alumina and zirconia is a key element for practical application using commercial bioethanol. HRTEM analysis of post mortem honeycombs loaded with $\mathrm{RhPd} / \mathrm{Ce}_{0.5} \mathrm{Zr}_{0.5} \mathrm{O}_{2}$ $-\mathrm{Al}_{2} \mathrm{O}_{3}$ showed no carbon formation and no metal agglomeration.

๑) 2016 Hydrogen Energy Publications LLC. Published by Elsevier Ltd. All rights reserved.
\end{abstract}

\section{Introduction}

On-board reforming has attracted attention in the last decades [1-6]. It consists in the transformation of liquid fuels to a hydrogen-rich gas in a vehicle by a catalytic process. Mixing the hydrogen-rich gas generated with the regular fuel employed by the internal combustion engine (ICE) results in important savings in fuel and reduction of gaseous and particulate emissions [7]. Also, even quite modest levels of hydrogen greatly improve smooth engine operation as well as flammability of the fuel and flame speed, thus resulting in higher engine thermal efficiency. Since reforming reactions are endothermic, the use of excess heat released by the exhaust gases from ICEs represents an excellent way to

\footnotetext{
* Corresponding author.

E-mail address: jordi.llorca@upc.edu (J. Llorca).
} 
provide with the necessary energy; otherwise a fraction of the fuel needs to be burned to generate the necessary heat, obviously incurring in an economy penalty. Among the different reforming technologies, steam reforming is more advantageous for improving ICE performance because of its higher hydrogen production and endothermic character, which helps to recover heat more efficiently from the engine exhaust heat. It provides a means for recycling exhaust energy in a chemical form. It is well known that about $30 \%$ of the fuel energy introduced to ICEs is wasted with engine exhaust gases, so its utilization can lead to a significant improvement of ICE energy efficiency. Previous works concerning on-board reforming focused mainly on methanol reforming because methanol has no $\mathrm{C}-\mathrm{C}$ bonds and the reforming temperature is low (around $300{ }^{\circ} \mathrm{C}$ ), whereas reforming of higher alcohols and hydrocarbons requires higher temperatures (typically $600-800{ }^{\circ} \mathrm{C}$ ) [1,8-12]. Gasoline reforming has potential for more widespread use than alcohols, but it also has greater technical barriers to overcome, most notably with respect to achieving effective reforming of the aromatic fraction. In recent years the production of renewable ethanol from biological sources (bioethanol) has increased strongly. In addition to sustainability and economic issues, ethanol is non-toxic, easy to handle, readily available and $\mathrm{CO}_{2}$-neutral, so its use for onboard reforming appears promising. The use of ethanol reformate as a fuel supplement in ICEs has shown engine efficiency improvement comparable to that reported for methanol reformate, 20-40\% [13,14]. Whereas several detailed studies concerning modeling for on-board reforming have been published [15-18], only a few works exist in the literature reporting experimental studies related to on-board ethanol reforming [5,19-21], and they mainly focus on the performance and exhaust emission characteristics of the engines. Here we attempt to focus on the catalyst in order to identify a suitable one for on-board ethanol reforming using exhaust heat from ICEs. In addition to high activity and fast response, a catalyst for on-board reforming should be very robust and coke formation should be avoided, which is certainly one of the main problems reported for this technology along with cold start difficulties.

We decided to explore the capabilities of two well-known catalysts with different reaction mechanism for the ethanol steam reforming (ESR) process: $\mathrm{C}_{2} \mathrm{H}_{5} \mathrm{OH}+3 \mathrm{H}_{2} \mathrm{O} \rightarrow 6 \mathrm{H}_{2}+2 \mathrm{CO}_{2}$ $\left(\Delta \mathrm{H}^{0}{ }_{298 \mathrm{~K}}=173.3 \mathrm{~kJ} \mathrm{~mol}^{-1}\right)$. There are two main pathways for ESR, which are sketched in Fig. 1. One of them involves the dehydrogenation of ethanol into acetaldehyde and hydrogen (Equation (1)) and the direct steam reforming of acetaldehyde into hydrogen and carbon monoxide (Equation (2)). This reaction mechanism is known to operate at moderate temperature over cobalt-based catalysts [22-27]. The second ESR pathway involves the initial decomposition of ethanol into a mixture of hydrogen, carbon monoxide and methane (Equation (3)). Then, and independently of the two pathways involved, carbon monoxide reacts with water to yield carbon dioxide and hydrogen through the water gas shift equilibrium (Equation (4)) and methane is reformed with water to a mixture of carbon monoxide and hydrogen (Equation (5)). This second reaction mechanism is favored over nickel- and noble metal-based catalysts, the latter being preferred because of less coke accumulation $[22,27,28]$.

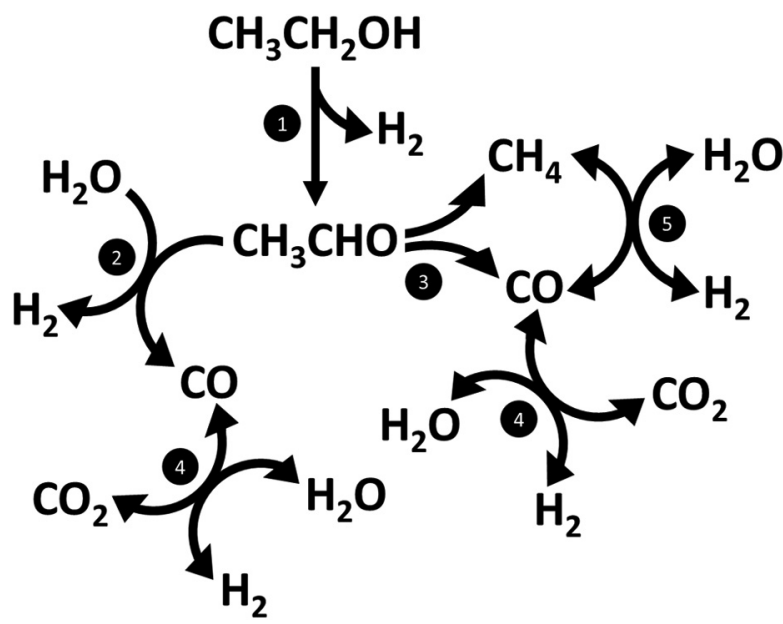

Fig. 1 - Scheme of the different reaction pathways and main reactions involved in the catalytic reforming of ethanol. 1: ethanol dehydrogenation, 2: acetaldehyde steam reforming, 3: acetaldehyde decomposition, 4: water gas shift, 5: methane steam reforming.

$\mathrm{C}_{2} \mathrm{H}_{5} \mathrm{OH} \rightarrow \mathrm{H}_{2}+\mathrm{CH}_{3} \mathrm{CHO}$

$\mathrm{CH}_{3} \mathrm{CHO}+\mathrm{H}_{2} \mathrm{O} \rightarrow 3 \mathrm{H}_{2}+2 \mathrm{CO}$

$\mathrm{C}_{2} \mathrm{H}_{5} \mathrm{OH} \rightarrow \mathrm{H}_{2}+\mathrm{CO}+\mathrm{CH}_{4}$

$\mathrm{CO}+\mathrm{H}_{2} \mathrm{O} \rightleftarrows \mathrm{H}_{2}+\mathrm{CO}_{2}$

$\mathrm{CH}_{4}+\mathrm{H}_{2} \mathrm{O} \rightleftarrows 3 \mathrm{H}_{2}+\mathrm{CO}$

In our study we have used a cobalt hydrotalcite catalyst doped with $\mathrm{K}^{+}$and two catalysts based on $\mathrm{RhPd} / \mathrm{CeO}_{2}$. Cobalt hydrotalcite doped with potassium is known for its good performance at moderate temperature $\left(500-550{ }^{\circ} \mathrm{C}\right)$ [29-31], and $\mathrm{RhPd} / \mathrm{CeO}_{2}$ has shown excellent catalytic performance and robustness for ESR at higher temperature $\left(600-750^{\circ} \mathrm{C}\right)$ in a variety of reactor configurations, including conventional packed bed reactors, structured reactors, microreactors and catalytic membrane reactors [32-35]. The works reported in the literature for the on-board reforming of ethanol with exhaust heat from ICEs have solely used the decomposition of ethanol (Equation (3)) at low temperature over copperbased catalysts $[19,20,36]$. However, the efficiency of ICEs fed by the low-temperature ethanol reformate is not advantageous, particularly at high loads, where the production of hydrogen is rather low [37]. Here we have performed, for the first time, the full steam reforming of ethanol using the exhaust heat from combustion gases in an ICE. The results discussed in this paper are focused on the reformer performance, which include examination of the reformer temperature, analysis of the reformate gases, and calculation of hydrogen production rates. 


\section{Experimental methods}

\section{Catalyst samples}

The Co/Mg/Al hydrotalcite with formula $\left[\mathrm{Co}_{2} \mathrm{Mg}_{4} \mathrm{Al}_{2}(\mathrm{OH})_{16}\right]$ $\mathrm{CO}_{3} \cdot 4 \mathrm{H}_{2} \mathrm{O}$ was prepared as described elsewhere [30] by coprecipitation from aqueous solutions of $\mathrm{Co}\left(\mathrm{NO}_{3}\right)_{2} \cdot 6 \mathrm{H}_{2} \mathrm{O}$, $\mathrm{Mg}\left(\mathrm{NO}_{3}\right)_{2} \cdot 6 \mathrm{H}_{2} \mathrm{O}$ and $\mathrm{Al}\left(\mathrm{NO}_{3}\right)_{3} \cdot 9 \mathrm{H}_{2} \mathrm{O}$ and $2 \mathrm{M} \mathrm{NaOH}$ alkaline solution at a constant $\mathrm{pH}$ of $10 \pm 0.5$. The resulting solid was thoroughly washed, dried at $100^{\circ} \mathrm{C}$ and calcined at $550{ }^{\circ} \mathrm{C}$ for $12 \mathrm{~h}$ to obtain the hydrotalcite-derived mixed oxide. Potassium addition to the calcined hydrotalcite (1.0 wt.\% referred to the nominal cobalt content) was accomplished by impregnation with $\mathrm{KOH}$ aqueous solution. The resulting catalyst was dried at $100{ }^{\circ} \mathrm{C}$ and calcined at $550{ }^{\circ} \mathrm{C}$ for $4 \mathrm{~h}$. Because reformer performance is heavily dependent upon catalyst temperature, metallic honeycombs were used to ensure efficient heat transfer from the ICE exhaust gases. The catalyst powder was deposited onto homemade fecralloy honeycombs (cylinders of $2.1 \mathrm{~cm}$ diameter and length, 1400 cells per square inch) by washcoating. The honeycombs were first treated at $900{ }^{\circ} \mathrm{C}$ to form a thin alumina layer over the channels to ensure good catalyst adherence. A 5:1 M mixture of polyvinyl alcohol (PVA) and acetic acid was used as binding agent. The resulting catalytic honeycombs were dried under rotation $(60 \mathrm{rpm})$ at $100{ }^{\circ} \mathrm{C}$ and calcined at $650{ }^{\circ} \mathrm{C}$ for $4 \mathrm{~h}$. The washcoating procedure was repeated until a catalyst specific load of ca. $1.5 \mathrm{mg} \mathrm{cm}^{-2}$.

The preparation of the catalytic honeycombs loaded with $\mathrm{RhPd} / \mathrm{CeO}_{2}$ involved two steps. First, the fecralloy honeycombs were washcoated with cerium dioxide prepared from $\mathrm{Ce}\left(\mathrm{NO}_{3}\right)_{2} \cdot 6 \mathrm{H}_{2} \mathrm{O}$ as described elsewhere [34], followed by $2 \mathrm{~h}$ drying at $100{ }^{\circ} \mathrm{C}$ under rotation and calcination at $650{ }^{\circ} \mathrm{C}$ for $4 \mathrm{~h}$. The washcoating procedure was repeated until a catalyst specific load of ca. $1.5 \mathrm{mg} \mathrm{cm} \mathrm{cm}^{-2}$. Noble metals were then added in a single step by dropwise incipient wetness impregnation, using a water/acetone $\mathrm{PdCl}_{2}$ and $\mathrm{RhCl}_{3}$ solution. Samples were dried at $100{ }^{\circ} \mathrm{C}$ and calcined at $650{ }^{\circ} \mathrm{C}$ for $4 \mathrm{~h}$. The noble metal loading was $0.5 \mathrm{wt} . \% \mathrm{Rh}$ and $0.5 \mathrm{wt} \% \mathrm{Pd}$ referred to the $\mathrm{CeO}_{2}$ support. Exactly the same procedure was employed to prepare catalytic honeycombs loaded with $\mathrm{RhPd} / \mathrm{Ce}_{0.5} \mathrm{Zr}_{0.5} \mathrm{O}_{2}-\mathrm{Al}_{2} \mathrm{O}_{3}$ with a $\mathrm{Ce}_{0.5} \mathrm{Zr}_{0.5} \mathrm{O}_{2}: \mathrm{Al}_{2} \mathrm{O}_{3}$ ratio of $1: 1 \mathrm{wt} . \%$, except that the support was prepared from $\mathrm{Ce}(\mathrm{N}-$ $\left.\mathrm{O}_{3}\right)_{2} \cdot 6 \mathrm{H}_{2} \mathrm{O}, \mathrm{ZrOCl}_{2} \cdot 8 \mathrm{H}_{2} \mathrm{O}$ and $\mathrm{AlO}(\mathrm{OH})$. The $\mathrm{Ce}_{0.5} \mathrm{Zr}_{0.5} \mathrm{O}_{2}$ solid solution was prepared directly by coprecipitation over a slurry of commercial boehmite (Disperal ${ }^{\circledR}$ ). In all cases homogeneous catalyst layers of about $40-60 \mu \mathrm{m}$ in thickness were obtained, exhibiting adherence values of $95-97 \%$ after ultrasound exposure. As a representative example, Fig. 2 shows two images recorded over the $\mathrm{RhPd} / \mathrm{CeO}_{2}$ honeycomb.

The characterization of the catalysts has been reported in detail previously, both for the potassium-doped Co hydrotalcite $[29,30]$ and for the $\mathrm{RhPd} / \mathrm{CeO}_{2}[32,34,35]$. In this work we have used scanning electron microscopy (SEM) and high resolution transmission electron microscopy (HRTEM) to study the catalysts before and after the reforming process to check for sintering phenomena and carbon deposition. SEM was carried out with a Zeiss Neon40 instrument equipped with a field emission source and operated at $5 \mathrm{kV}$. HRTEM was performed in a JEOL 2010F microscope equipped with a field emission electron source and operated at an accelerating voltage of $200 \mathrm{kV}$. The point-to-point resolution was $0.19 \mathrm{~nm}$, and the resolution between lines was $0.14 \mathrm{~nm}$. Samples were dispersed in an alcohol suspension in an ultrasonic bath, and a drop of the suspension was placed over a grid with holey-carbon film. Images were not filtered or treated by means of digital processing and they correspond to raw data.

\section{Testing system}

A schematic view of the testing bench is depicted in Fig. 3. The engine used in this study was a conventional Honda GX390, which is a $0.39 \mathrm{~L}$, 4-stroke, single-point injection, single cylinder gasoline engine. All the experiments were carried out at an engine speed of $3000 \mathrm{rpm}$ (net power of $11 \mathrm{HP}$ and net torque of $26 \mathrm{~N} \mathrm{~m}$ ). The engine was connected to a $5.5 \mathrm{kV} \mathrm{A}, 400 \mathrm{~V}, 50 \mathrm{~Hz}$, three-phase alternator working at an electrical load of $0.5 \mathrm{~kW}$. The catalytic honeycombs were installed in a stainless steel tubular reactor $(25 \mathrm{~mm} \mathrm{OD}$, $25 \mathrm{~mm}$ length, $2 \mathrm{~mm}$ wall thickness), which was positioned perpendicular to the exhaust gas stream of the engine and welded to the exhaust pipe. The experiments were conducted after the engine was fully warmed up. The feedstock consisting of ethanol/bioethanol (Deulep) and water was provided directly from a storage tank and pumped at the desired flow rate using an HPLC pump (Knauer Smartline). The feedstock was firstly transformed from the liquid phase into gaseous phase before entering the reactor by the exhaust heat in the heat pipe in a $1 / 8^{\prime \prime}$ OD stainless-steel tube wrapped around the reactor. Several K-type thermocouples were placed at different positions of the exhaust pipe, which measured temperatures in the range $350-730{ }^{\circ} \mathrm{C}$, and one thermocouple was placed in direct contact with the center of the catalytic honeycomb, which allowed a continuous monitoring of the temperature during the experiments. The catalytic honeycombs were tested directly, i.e. without any pretreatment.

The flowrates of the engine exhaust gas (580 STP L $\cdot \mathrm{min}^{-1}$ ) and the reformate gas were measured at ambient conditions and the reformate gas was analyzed by gas chromatography (GC) with an Agilent 3000A instrument equipped with Molecular Sieve $5 \AA$, Plot $U$ and Stabilwax columns and TCD detectors. Measurements were replicated with adequate reproducibility. $\mathrm{H}_{2}, \mathrm{CO}_{2}, \mathrm{CO}$ and $\mathrm{CH}_{4}$ were the main reaction products in all cases whereas negligible amounts of acetaldehyde, ethane, ethylene and acetone were measured by GC. For selected catalyst formulations uninterrupted long-term runs exceeding $200 \mathrm{~h}$ were conducted to test for catalyst stability. Hydrogen yield ( $\mathrm{Y}_{\mathrm{H} 2}$, Equation (6)) was defined as the amount of recovered hydrogen in the reformate (molar flowrate, $F_{\mathrm{H}_{2} \text {,out }}$ ) with respect to the ethanol/bioethanol amount in the feedstock $\left(\mathrm{F}_{\mathrm{EtOH}, \mathrm{in}}\right)$ taking into account the stoichiometry of the ideal process (equation (1)).

$$
\mathrm{Y}_{\mathrm{H}_{2}}=\mathrm{F}_{\mathrm{H}_{2}, \text { out }} / 6 \mathrm{~F}_{\mathrm{EtOH}, \mathrm{in}}
$$



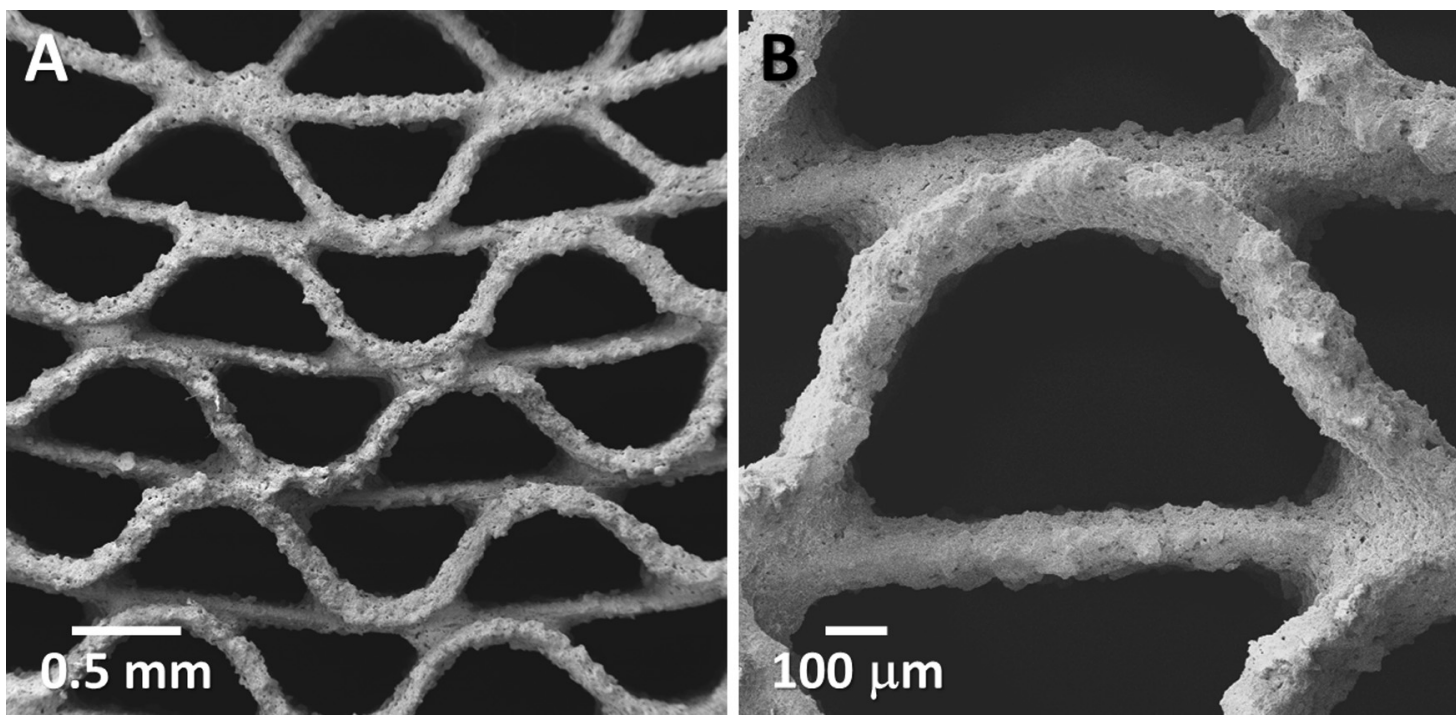

Fig. 2 - SEM images of the catalytic honeycomb loaded with $\mathrm{RhPd} / \mathrm{CeO}_{2}$.

\section{Results and discussion}

\section{Catalytic performance of $\mathrm{K}^{+}$-doped cobalt hydrotalcite}

The yield of reformate gas obtained over the catalytic honeycomb loaded with $\mathrm{K}^{+}$-doped cobalt hydrotalcite at different liquid load of ethanol and water is shown in Fig. 4A. The steam to carbon $(\mathrm{S} / \mathrm{C})$ ratio was fixed at $\mathrm{S} / \mathrm{C}=3$ and the measurements were done from low to high liquid load. The error bars correspond to the deviation from 6 to 9 different measurements. Also in Fig. 4A the temperature recorded at the catalytic honeycomb is plotted at each condition. It is clearly seen that the temperature was maintained at about $620^{\circ} \mathrm{C}$ in all the range of experiments, independently of the load of reactants. This is an indication that heat from the exhaust gases of the ICE was transferred effectively to the catalytic device, and that the rate of heat consumed by the steam reforming process

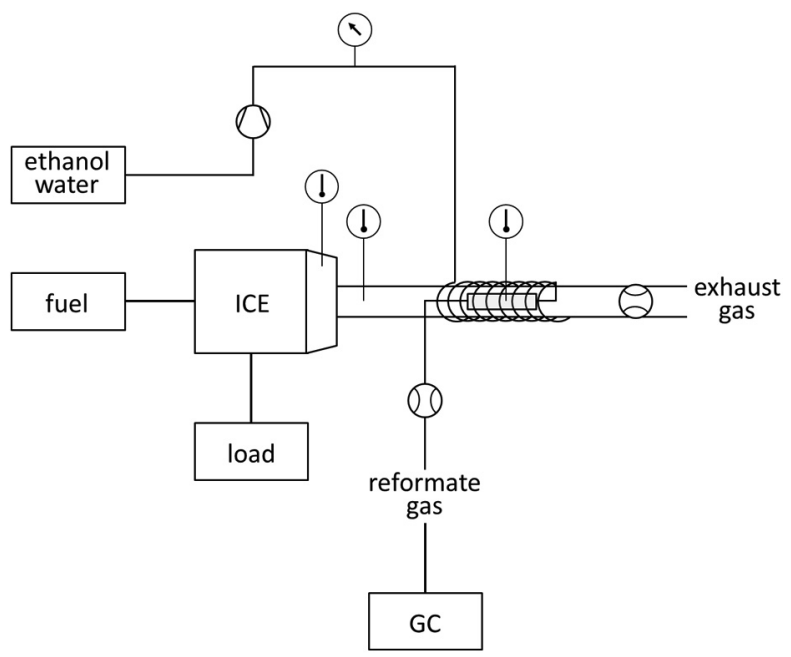

Fig. 3 - Scheme of the reaction test bench. was always lower than the rate of heat transferred from the exhaust gases of the ICE to the reformer. However, the production rate of reformate gas did not follow the increase of the load of reactants. For liquid feed rates up to $0.05 \mathrm{~mL}$ liq $\mathrm{min}^{-1}$ $\left(\mathrm{F} / \mathrm{W}<25 \mathrm{~mL}_{\text {liq }} \cdot \mathrm{g}_{\text {cat }}^{-1} \cdot \mathrm{h}^{-1}, \mathrm{GHSV}=4 \cdot 10^{2} \mathrm{~h}^{-1}\right)$ the production rate of reformate gas progressively increased, but at higher
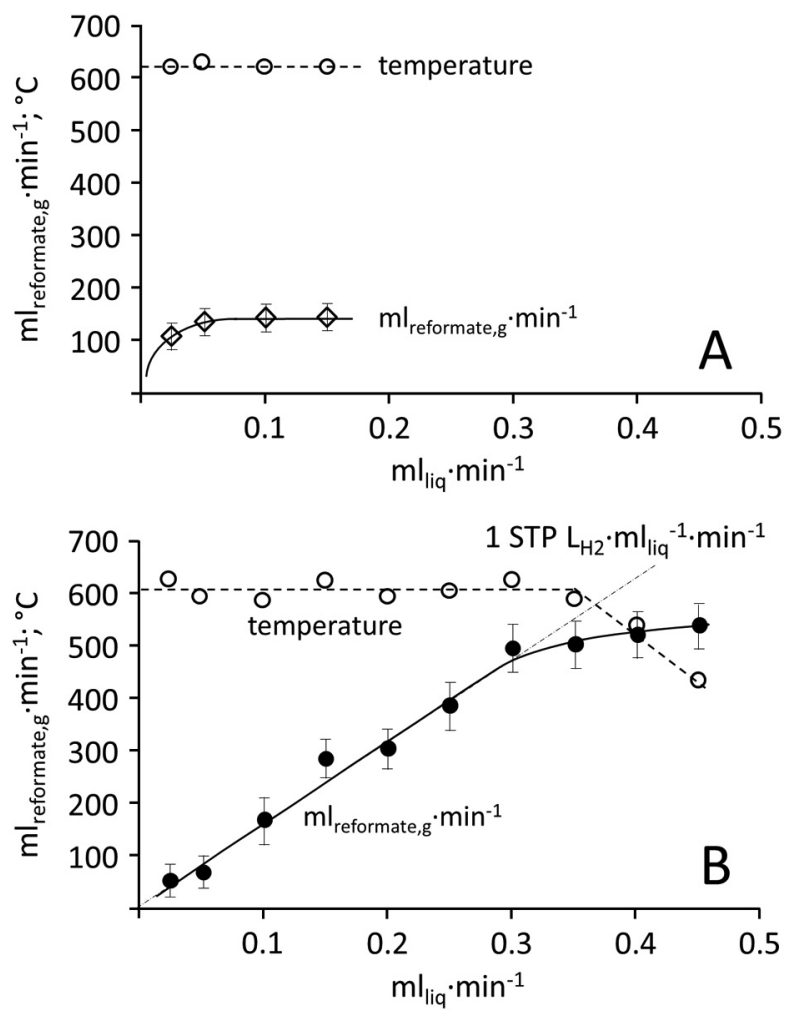

Fig. 4 - Reformate gas flowrates obtained under different liquid feedstock loads (ethanol-water, $\mathrm{S} / \mathrm{C}=3$ ) and temperatures over catalytic honeycombs loaded with potassium-doped cobalt hydrotalcite (A) and $\mathrm{RhPd} / \mathrm{CeO}_{2}(\mathrm{~B})$. 
liquid feed rates the production of reformate gas was maintained constant at about $128 \mathrm{~mL} \mathrm{~min}^{-1}$. Taking into account that the temperature of the reformer did not vary, this means that the intrinsic activity of the catalyst strongly limited the reforming process. The selectivity of products in the reformate gas (dry basis) under a liquid fed rate of $0.05 \mathrm{~mL}$ liq $\cdot \mathrm{min}^{-1}$ was ca. $66 \% \mathrm{H}_{2}, 16 \% \mathrm{CO}_{2}, 14 \% \mathrm{CO}$ and $4 \% \mathrm{CH}_{4}$, and the hydrogen yield was $88 \%$. The activity of the hydrotalcite catalyst therefore was $0.61 \mathrm{STP} \mathrm{L}_{\mathrm{H} 2} \cdot \mathrm{g}_{\text {cat }}^{-1} \cdot \mathrm{min}^{-1}$.

It is important to highlight that the carbon balance (carbon molar rate in the reformate gas with respect to carbon molar rate of ethanol) was close to $100 \%$ for liquid feed rates below $0.05 \mathrm{~mL}_{\text {liq }} \cdot \mathrm{min}^{-1}$, but it was progressively lower as the liquid feed rate increased $\left(68 \%\right.$ at $\left.0.15 \mathrm{~mL}_{\text {liq }} \cdot \mathrm{min}^{-1}\right)$, suggesting that carbon deposition occurred. At the end of the reforming tests the $\mathrm{K}^{+}$-doped cobalt hydrotalcite catalytic honeycomb was removed and examined by SEM. Fig. 5 shows a representative image of the surface of the catalyst corresponding to secondary electrons (Fig. 5A) and backscattered electrons (Fig. 5B). Numerous carbon filaments can be recognized in the image recorded with secondary electrons, whereas the bright dots in the image recorded with backscattered electrons are ascribed to metal cobalt nanoparticles, which have formed by reduction of the cobalt hydrotalcite during the reforming reaction and pulled outwards by the carbon filaments [29]. Probably, coke formation occurred through the dehydration of ethanol into ethylene over acidic sites associated to the presence of $\mathrm{Al}$ in the hydrotalcite structure, which is a wellknown coke precursor, or by the Boudouard reaction, $2 \mathrm{CO} \rightarrow \mathrm{C}+\mathrm{CO}_{2}$ [22]. Therefore we can conclude that on-board ethanol reforming over the $\mathrm{K}^{+}$-doped cobalt hydrotalcite honeycomb is not adequate. On one hand, the intrinsic activity of the catalytic honeycomb is low and, on the other hand, there is accumulation of large quantities of carbon, which is inadmissible for real application.

\section{Catalytic performance of $\mathrm{RhPd} / \mathrm{CeO}_{2}$}

Fig. 4B shows the yield of reformate gas obtained over the catalytic honeycomb loaded with $\mathrm{RhPd} / \mathrm{CeO}_{2}$ at different liquid load of ethanol and water as well as the temperature recorded inside the catalytic honeycomb at each condition. In this case, the overall production of reformate gas was much higher than that obtained with the honeycomb loaded with the $\mathrm{K}^{+}$-doped cobalt hydrotalcite discussed above. The amount of reformate gas increased linearly with the liquid load up to $0.3 \mathrm{~mL}$ liq $\cdot \mathrm{min}^{-1}\left(\mathrm{~F} / \mathrm{W}=150 \mathrm{~mL}\right.$ liq $\cdot \mathrm{g}_{\text {cat }}^{-1} \cdot \mathrm{h}^{-1}$, GHSV $\left.=2.4 \cdot 10^{3} \mathrm{~h}^{-1}\right)$, reaching production rates up to ca. $500 \mathrm{~mL} \mathrm{~min}^{-1}$ and hydrogen specific production rates of ca. 1 STP $\mathrm{L}_{\mathrm{H} 2} \cdot \mathrm{mL}_{\mathrm{liq}}^{-1} \cdot \mathrm{min}^{-1}$. In this interval, the temperature of the catalytic honeycomb was maintained always at about $610^{\circ} \mathrm{C}$ (Fig. 4B). At liquid loads higher than $0.3 \mathrm{~mL}_{\mathrm{liq}} \cdot \mathrm{min}^{-1}$ the production of reformate gas increased only slightly and, at the same time, the temperature of the catalytic honeycomb decreased strongly. This can be interpreted in terms of heat transfer limitations between the heat provided by the exhaust gas of the ICE and the reformer, which requires a higher amount of heat to complete the strongly endothermic steam reforming process as the liquid load increases. Therefore, the amount of reformate gas is not limited by the activity of the $\mathrm{RhPd} / \mathrm{CeO}_{2}$ catalyst, but by heat transfer. This is an important result and indicates that the $\mathrm{RhPd} / \mathrm{CeO}_{2}$ catalyst is appropriate for on-board ethanol steam reforming using the exhaust heat from combustion gases in an ICE. Obviously, the efficiency of the reforming process can be improved by optimizing the architecture of the reformer to enhance the heat transfer inside the exhaust gas pipe, which is beyond the purpose of this work.

The selectivity of the reformate gas obtained using a liquid load up to $0.3 \mathrm{~mL}_{\mathrm{liq}} \cdot \mathrm{min}^{-1}$ was maintained at approximately $58 \% \mathrm{H}_{2}, 24 \% \mathrm{CO}_{2}, 1 \% \mathrm{CO}$ and $17 \% \mathrm{CH}_{4}$. These selectivity values
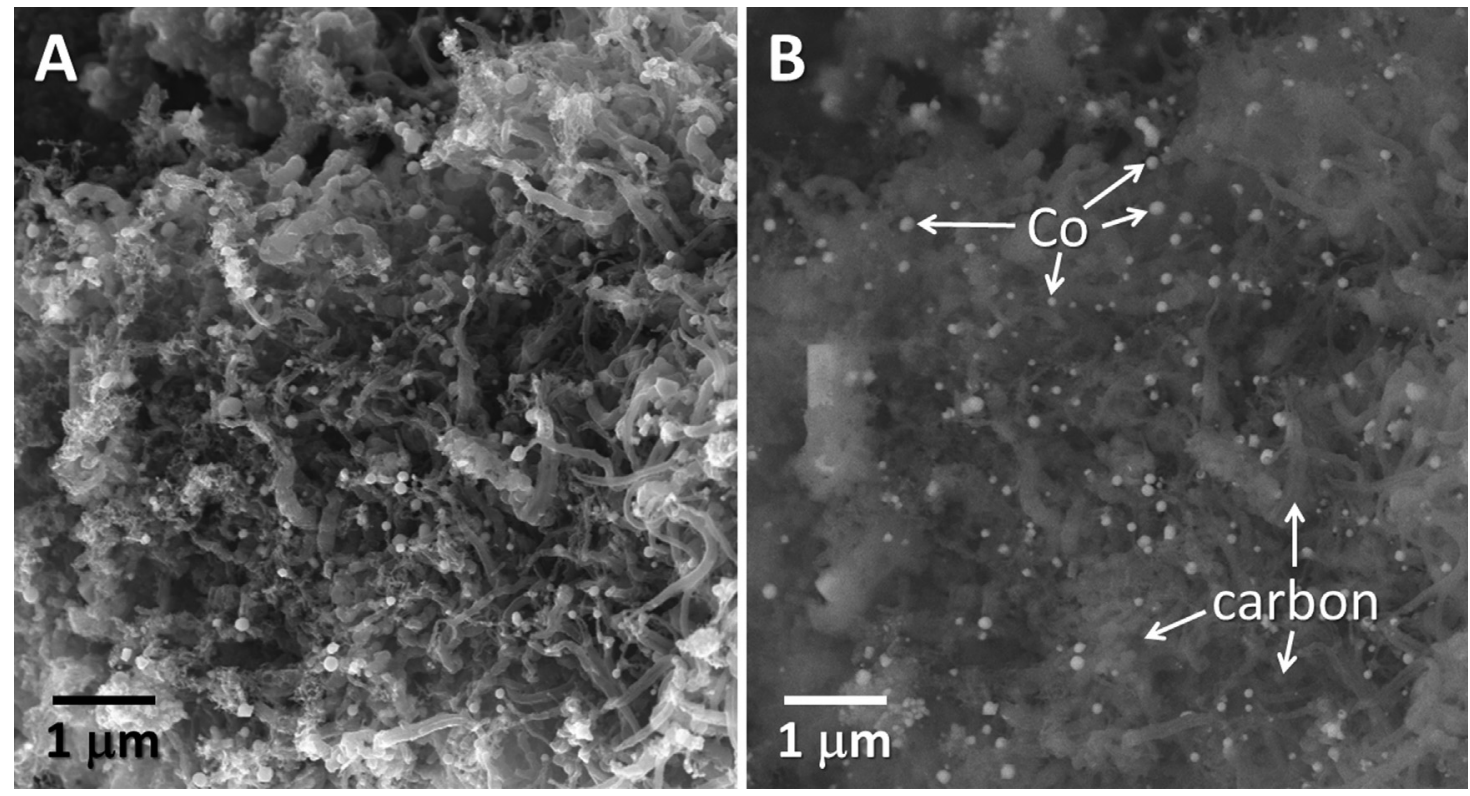

Fig. 5 - Secondary electron (A) and backscattered electron (B) SEM images of the potassium-doped cobalt hydrotalcite catalyst after reaction. 
are different from those recorded over the honeycomb loaded with $\mathrm{K}^{+}$-doped cobalt hydrotalcite discussed in Section Catalytic performance of $\mathrm{K}+$-doped cobalt hydrotalcite, in accordance to the different reaction mechanism exhibited by the cobalt hydrotalcite and the $\mathrm{RhPd} / \mathrm{CeO}_{2}$ catalyst $[28,29]$. In particular, the amount of $\mathrm{CO}$ in the reformate gas produced over the $\mathrm{RhPd} / \mathrm{CeO}_{2}$ catalyst is much lower due to its high activity in the water gas shift reaction, whereas the amount of $\mathrm{CH}_{4}$ is considerably higher because the ethanol steam reforming over the $\mathrm{RhPd} / \mathrm{CeO}_{2}$ catalyst proceeds through the decomposition of ethanol followed by the steam reforming of methane (Fig. 1). For that reason, the hydrogen yield was lower over the catalytic honeycomb loaded with $\mathrm{RhPd} / \mathrm{CeO}_{2}$ with respect to that obtained over the honeycomb loaded with the cobalt hydrotalcite, 77 vs. $88 \%$. However, the higher intrinsic activity of the $\mathrm{RhPd} / \mathrm{CeO}_{2}$ catalyst compared to that exhibited by the cobalt hydrotalcite (2.42 vs. 0.61 STP $\mathrm{L}_{\mathrm{H} 2} \cdot \mathrm{g}_{\mathrm{cat}}^{-1} \cdot \mathrm{min}^{-1}$ ) results in an overall higher hydrogen production in the former. Considering the superior catalytic performance of the honeycomb loaded with the $\mathrm{RhPd} / \mathrm{CeO}_{2}$ catalyst, a series of experiments were conducted with commercial bioethanol under the same operation conditions (F/ $\mathrm{W}=150 \mathrm{~mL}_{\text {liq }} \cdot \mathrm{g}_{\text {cat }}^{-1} \cdot \mathrm{h}^{-1}, \mathrm{GHSV}=2.4 \cdot 10^{3} \mathrm{~h}^{-1}$ ). In all cases, the production of reformate gas was slightly lower than that obtained with the pure ethanol-water mixture, about $5 \%$ less. This can be due to the presence of impurities in bioethanol, as reported elsewhere [38].

\section{Stability test}

We decided to run steam reforming long-term experiments with commercial bioethanol at $\mathrm{S} / \mathrm{C}=3$ over the catalytic honeycomb loaded with $\mathrm{RhPd} / \mathrm{CeO}_{2}$ to study the practical utilization of this catalyst for the on-board generation of hydrogen. Fig. $6 \mathrm{~A}$ shows the distribution of products in the reformate gas over $200 \mathrm{~h}$ on stream with a liquid load of $0.3 \mathrm{~mL}_{\text {liq }} \cdot \mathrm{min}^{-1}\left(\mathrm{~F} / \mathrm{W}=150 \mathrm{~mL}_{\text {liq }} \cdot \mathrm{g}_{\text {cat }}^{-1} \cdot \mathrm{h}^{-1}, \mathrm{GHSV}=2.4 \cdot 10^{3} \mathrm{~h}^{-1}\right)$ and ca. $610{ }^{\circ} \mathrm{C}$. The catalytic honeycomb showed a stable behavior for about $100 \mathrm{~h}$; after this period of time the concentration of $\mathrm{H}_{2}$ and $\mathrm{CO}_{2}$ decreased progressively and that of $\mathrm{CO}$ increased strongly. In addition, after $150 \mathrm{~h}$ on stream the concentration of $\mathrm{CH}_{4}$ also increased. Therefore it appears that the water gas shift reaction was suppressed over the catalytic honeycomb after bioethanol steam reforming for $100 \mathrm{~h}$ and also the steam reforming of methane was hindered after $150 \mathrm{~h}$. This is a clear indication that the active centers of the catalyst transform during reaction or are covered by carbon, or both. The catalytic honeycomb was studied by HRTEM before and after the stability test. Fig. 7 show representative lattice-fringe images of the catalytic layer as deposited (A and B) and after the long-term catalytic test ( $C$ and $D)$. The sample as prepared is constituted by RhPd nanoparticles very well dispersed over the ceria support, in accordance to previous works [32,34]. The particle size distribution of the noble metal nanoparticles ranges from 3 to $5 \mathrm{~nm}$ in diameter (Fig. 7A). The lattice fringes at $2.22 \AA$ in the nanoparticle depicted in detail in Fig. 7B, for instance, correspond to the (111) crystallographic planes of RhPd alloy. The metal nanoparticles are well-defined and perfectly anchored over the ceria support. In contrast, the catalyst after reaction exhibits a different structure. The size

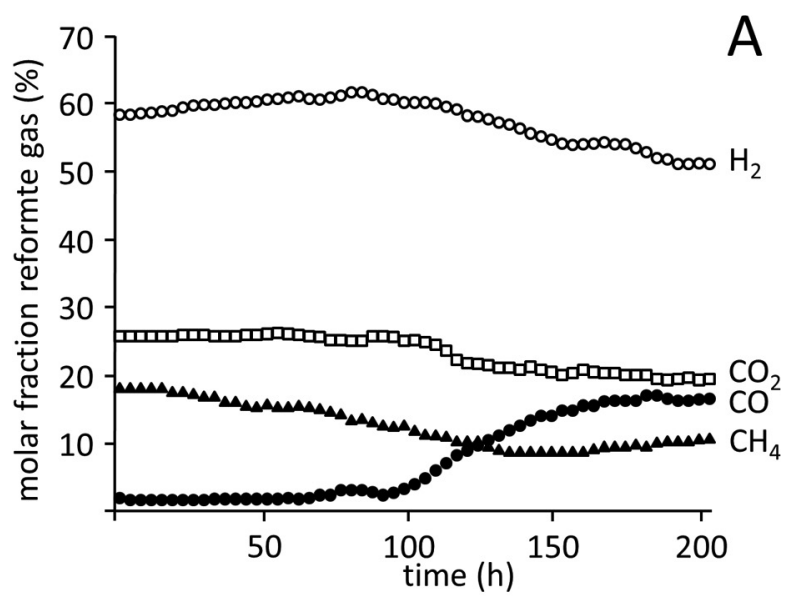

B

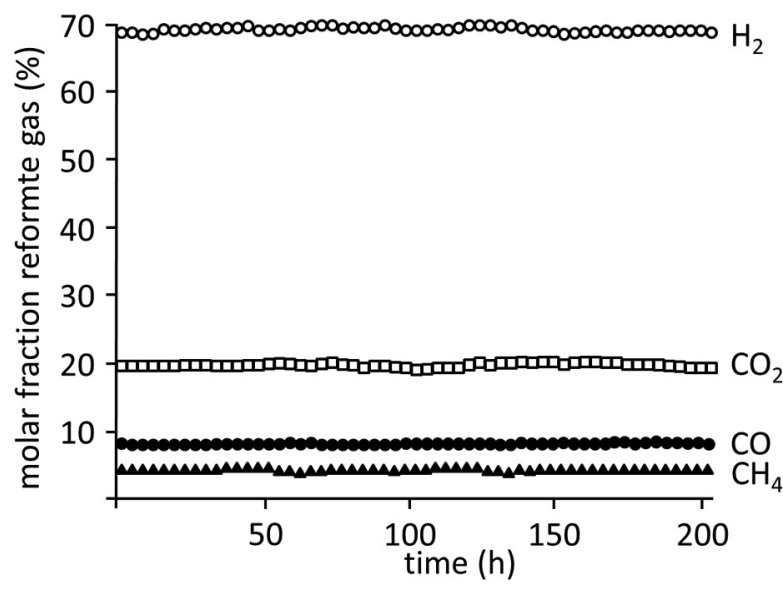

Fig. 6 - Selectivity values of the reformate gas obtained in long-term tests with commercial bioethanol (F/ $\mathrm{W}=150 \mathrm{~mL}_{\mathrm{liq}} \cdot \mathrm{g}_{\mathrm{cat}}^{-1} \mathrm{~h}^{-1}, \mathrm{~S} / \mathrm{C}=3, \mathrm{GHSV}=2.4 \cdot 10^{3} \mathrm{~h}^{-1}$ ) over $\mathrm{RhPd} / \mathrm{CeO}_{2}$ (A) and $\mathrm{RhPd} / \mathrm{Ce}_{0.5} \mathrm{Zr}_{0.5} \mathrm{O}_{2}-\mathrm{Al}_{2} \mathrm{O}_{3}$ (B).

of the metal nanoparticles is preserved at about $3-5 \mathrm{~nm}$ and no sintering is detected. However, the metal nanoparticles are no longer well anchored over the ceria support because carbon formation has occurred, which has detached the nanoparticles from the support. This is clearly seen in Fig. 7C, where a metal nanoparticle is separated by carbon from the ceria support. The lattice fringes of the nanoparticle at 2.22-2.23 \& correspond to the (111) crystallographic planes of RhPd alloy. Fig. 7D shows carbon accumulation over both the metal nanoparticles as well as over the ceria support. This explains well the change of the distribution of products in the reformate gas; the most active and selective sites for the ethanol steam reforming reaction (including the water gas shift reaction) have been associated with the periphery of the RhPd alloy nanoparticles in contact with $\mathrm{CeO}_{2}$ [32]. As soon as carbon accumulation occurs, it provokes the detachment of the nanoparticles from the support and the specific catalytic active sites are progressively lost.

In order to avoid carbon accumulation during the reforming of bioethanol, a different support formulation was tested based on previous results reported in the literature [39]. The formulation of the support contained $\mathrm{Al}_{2} \mathrm{O}_{3}$ and $\mathrm{Ce}_{0.5} \mathrm{Zr}_{0.5} \mathrm{O}_{2}$. 

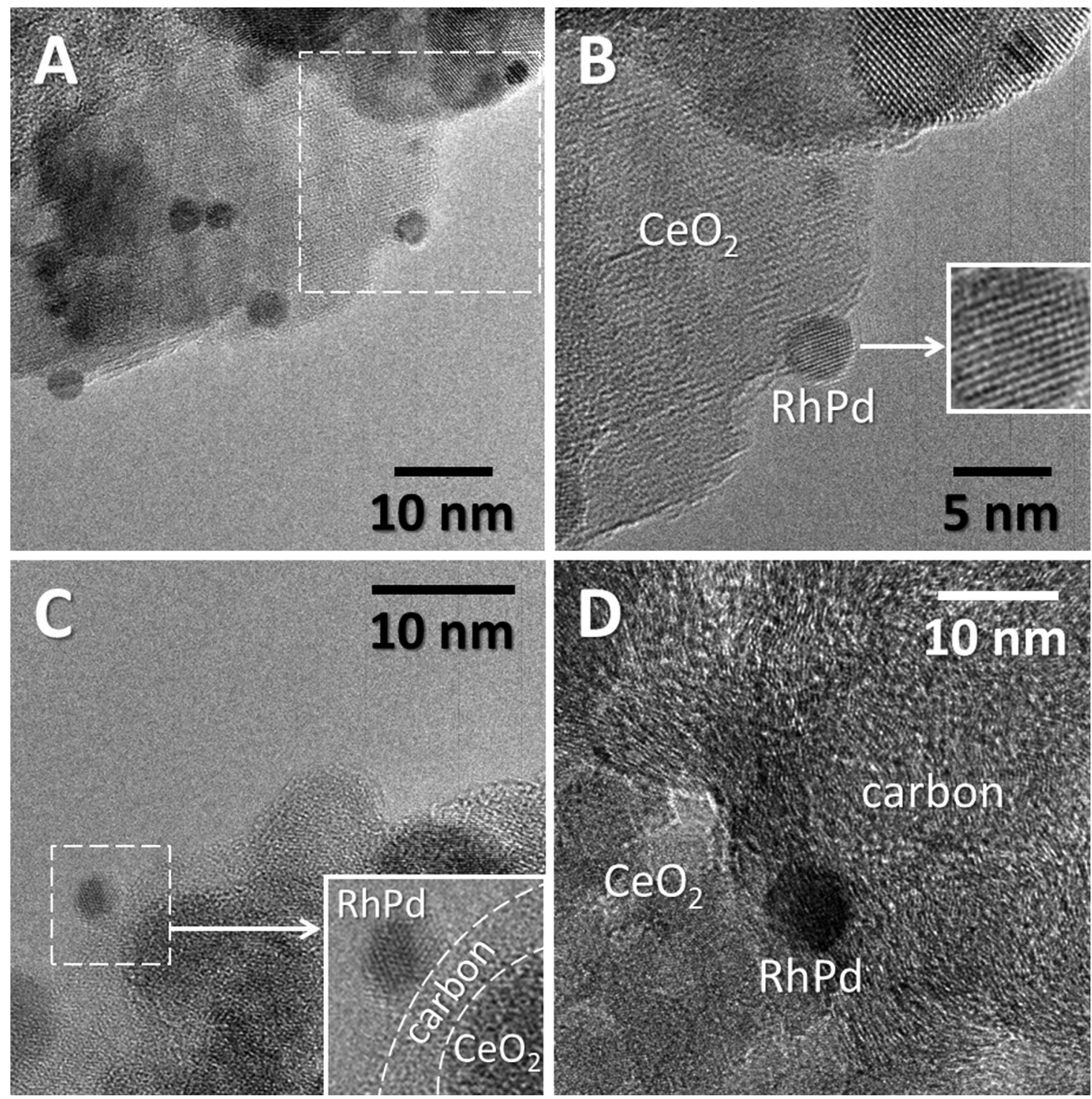

Fig. 7 - HRTEM images of the $\mathrm{RhPd} / \mathrm{CeO}_{2}$ catalyst as prepared (A, B) and after reaction with commercial bioethanol (F/ $\mathrm{W}=150 \mathrm{~mL}_{\text {liq }} \cdot \mathrm{g}_{\text {cat }}^{-1} \cdot \mathrm{h}^{-1}, \mathrm{~S} / \mathrm{C}=3, \mathrm{GHSV}=2.4 \cdot 10^{3} \mathrm{~h}^{-1}$ ) for $200 \mathrm{~h}(\mathrm{C}, \mathrm{D})$.

Ceria-zirconia solid solution is well known for its enhanced oxygen storage capacity $[40,41]$, which has a fundamental role in avoiding carbon deposition [42]. Recently it has been reported that the contact points between carbon and ceria-zirconia solid solution are prone to create oxygen vacancies, which are very active in suppressing carbon accumulation [43]. The role of alumina is to provide with acid sites for water activation, which promotes the water gas shift and the methane steam reforming steps of the reforming process, and also to enhance the thermal stability of $\mathrm{Ce}_{0.5} \mathrm{Zr}_{0.5} \mathrm{O}_{2}$ $[38,39]$. Fig. $6 \mathrm{~B}$ shows the distribution of products in the reformate gas over $200 \mathrm{~h}$ on stream over $\mathrm{RhPd} / \mathrm{Ce}_{0.5} \mathrm{Zr}_{0.5} \mathrm{O}_{2}$ $-\mathrm{Al}_{2} \mathrm{O}_{3}$ under strictly the same operation conditions. Two aspects merit to be highlighted. First, the distribution of products was maintained absolutely constant during the duration of the long-term test. Second, the distribution of products in the reformate gas was different from that obtained over the catalytic honeycomb loaded with $\mathrm{RhPd} / \mathrm{CeO}_{2}$.
In particular, the hydrogen yield was considerable higher in the reformate gas obtained over $\mathrm{RhPd} / \mathrm{Ce}_{0.5} \mathrm{Zr}_{0.5} \mathrm{O}_{2}-\mathrm{Al}_{2} \mathrm{O}_{3}, 93$ vs. $77 \%$. Also, the $\mathrm{CO}$ and $\mathrm{CH}_{4}$ concentrations were kept always below $10 \%$ and $5 \%$, respectively, which indicate a high activity and robustness of the catalyst towards the water gas shift reaction and methane steam reforming. Clearly, both the specificity and stability of the catalytic honeycomb loaded with $\mathrm{RhPd} / \mathrm{Ce}_{0.5} \mathrm{Zr}_{0.5} \mathrm{O}_{2}-\mathrm{Al}_{2} \mathrm{O}_{3}$ was superior. After the longterm test, the $\mathrm{RhPd} / \mathrm{Ce}_{0.5} \mathrm{Zr}_{0.5} \mathrm{O}_{2}-\mathrm{Al}_{2} \mathrm{O}_{3}$ catalyst was examined by HRTEM. Fig. 8 shows images of the catalyst as prepared (Fig. 8A and B) and after reaction (Fig. 8C and D). The fresh sample contains metal nanoparticles of about 3-4 $\mathrm{nm}$ in size, which are very well distributed over the $\mathrm{Ce}_{0.5} \mathrm{Zr}_{0.5} \mathrm{O}_{2}$ $-\mathrm{Al}_{2} \mathrm{O}_{3}$ support. The nanoparticles are well anchored (see for example Fig. 8B) and exhibit lattice fringes at $2.22 \AA$ corresponding to the characteristic (111) crystallographic planes of RhPd alloy. Interestingly, after reaction there are no significant changes in the architecture of the catalyst. The size of the 

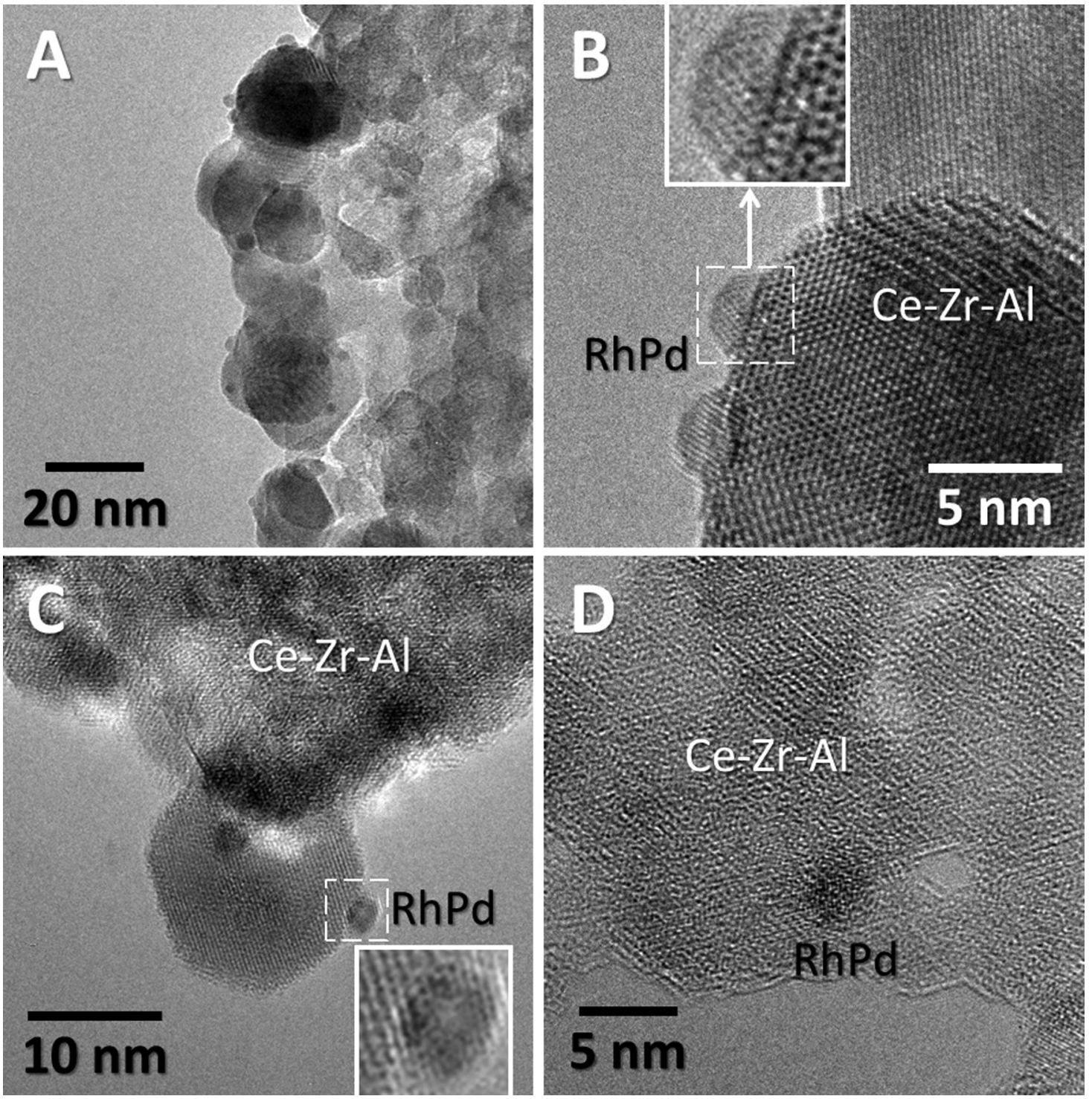

Fig. 8 - HRTEM images of the RhPd/Ce-Zr-Al catalyst as prepared (A, B) and after reaction with commercial bioethanol (F/ $\mathrm{W}=150 \mathrm{~mL}_{\text {liq }} \cdot \mathrm{g}_{\mathrm{cat}}^{-1} \cdot \mathrm{h}^{-1}, \mathrm{~S} / \mathrm{C}=3, \mathrm{GHSV}=2.4 \cdot 10^{3} \mathrm{~h}^{-1}$ ) for $200 \mathrm{~h}(\mathrm{C}, \mathrm{D})$.

metal nanoparticles was maintained at 3-4 $\mathrm{nm}$ and, most importantly, there are no signs of carbon accumulation, neither in the form of carbon nanotubes or nanofibers or carbon shells. The lattice fringes of the nanoparticles are well preserved and the nanoparticles are well anchored onto the support.

\section{Conclusions}

Catalytic honeycombs loaded with potassium-promoted cobalt hydrotalcite, $\mathrm{RhPd} / \mathrm{CeO}_{2}$, and $\mathrm{RhPd} / \mathrm{Ce}_{0.5} \mathrm{Zr}_{0.5} \mathrm{O}_{2}-\mathrm{Al}_{2} \mathrm{O}_{3}$ catalysts were tested for the on-board steam reforming of ethanol and commercial bioethanol $(\mathrm{S} / \mathrm{C}=3)$ under gas hourly space velocity (GHSV) values of $2 \cdot 10^{2}-4 \cdot 10^{3} \mathrm{~h}^{-1}$. The reforming process was conducted inside the housing of the exhaust gas pipe of a Honda GX390 gasoline internal combustion engine (ICE) by using the heat of the exhaust gases (at about $610-620^{\circ} \mathrm{C}$ ) to produce a reformate gas that could be injected into the ICE to save fuel and reduce gaseous and particulate emissions. The production of hydrogen over the catalytic honeycomb loaded with the potassium-promoted cobalt hydrotalcite was very effective at low reactant load (up to GHSV $=4 \cdot 10^{2} \mathrm{~h}^{-1}$ ), but it was severely limited by the intrinsic activity of the catalysts and coke formation, making its use impractical. The catalytic monolith loaded with RhPd/ $\mathrm{CeO}_{2}$ showed high activity for ethanol reforming, reaching values of about $1 \mathrm{STP} \mathrm{L}_{\mathrm{H} 2} \cdot \mathrm{mL}_{\mathrm{liq}}^{-1} \cdot \mathrm{min}^{-1}$ up to GHSV values of $2.4 \cdot 10^{3} \mathrm{~h}^{-1}$. At higher reactant load the production of hydrogen decreased because the temperature of the catalytic honeycomb decreased strongly due to heat transfer limitations between the heat provided by the exhaust gas of the ICE and the reformer. Long duration reforming tests performed with commercial bioethanol $\left(\mathrm{S} / \mathrm{C}=3, \mathrm{GHSV}=2.4 \cdot 10^{3} \mathrm{~h}^{-1}\right)$ over the catalytic honeycomb loaded with $\mathrm{RhPd} / \mathrm{CeO}_{2}$ resulted in loss of hydrogen production due to the progressive 
transformation of the catalyst; in particular the RhPd metal nanoparticles detached from the support by accumulation of carbon. In contrast, when the ceria catalytic support was substituted by $\mathrm{Ce}_{0.5} \mathrm{Zr}_{0.5} \mathrm{O}_{2}-\mathrm{Al}_{2} \mathrm{O}_{3}$ the catalytic performance of the resulting $\mathrm{RhPd} / \mathrm{Ce}_{0.5} \mathrm{Zr}_{0.5} \mathrm{O}_{2}-\mathrm{Al}_{2} \mathrm{O}_{3}$ catalytic honeycomb was greatly enhanced for bioethanol reforming, with excellent stability and absence of carbon accumulation. This catalyst is considered as a good candidate for practical onboard ethanol reforming using the excess heat provided by exhaust gases in ICEs.

\section{Acknowledgments}

This work has been funded through grant ENE2015-63969-R (MINECO/FEDER). J.L. is Serra Húnter Fellow and is grateful to ICREA Academia program.

\section{R E F E R E N C E S}

[1] Kolb G. Fuel processing. New York: Wiley-VCH; 2008.

[2] Fennell D, Herreros JM, Tsolakis A. Improving gasoline direct injection (GDI) engine efficiency and emissions with hydrogen from exhaust gas fuel reforming. Int J Hydrogen Energy 2014;39:5153-62.

[3] Golunski S. What is the point of on-board fuel reforming? Energy Environ Sci 2010;3:1918-23.

[4] Fennell D, Herreros J, Tsolakis A, Cockle K, Pignon J, Millington P. Thermochemical recovery technology for improved modern engine fuel economy - part 1: analysis of a prototype exhaust gas fuel reformer. RSC Adv 2015;5:35252-61.

[5] Park C, Choi Y, Kim C, Oh S, Lim G, Moriyoshi Y. The performance and exhaust emission characteristics of a spark ignition engine using ethanol and ethanol-reformed gas. Fuel 2010;89:2118-25.

[6] Hirota T. Study of the methanol-reformed gas engine. JSAE Rev 1981;4:7-13.

[7] He Z, Gao Z, Zhu L, Li S, Li A, Zhang W, et al. Effects of $\mathrm{H}_{2}$ and $\mathrm{CO}$ enrichment on the combustion, emission and performance characteristics of spark ignition natural gas engine. Fuel 2016;183:230-7.

[8] Petterson L, Sjostrom K. Decomposed methanol as a fuel-a review. Combust Sci Technol 1991:265-303.

[9] Chrenko D, Gao F, Bluier B, Bouquain D, Miraoui A. Methanol fuel processor and PEM fuel cell modeling for mobile application. Int J Hydrogen Energy 2010;35:6863-71.

[10] Chein RY, Chen YC, Chang CM, Chung JN. Experimental study on the performance of hydrogen production from a miniature methanol-steam reformer integrated with Swissroll type combustor for PEMFC. Appl Energy 2013;105:86-98.

[11] Aicher T, Full J, Schaadt A. A portable fuel processor for hydrogen production from ethanol in a $250 \mathrm{~W}_{\mathrm{el}}$ fuel cell system. Int J Hydrogen Energy 2009;34:8006-15.

[12] Gardemann U, Steffen M, Heinzel A. Design and demonstration of an ethanol fuel processor for PEM fuel cell applications. Int J Hydrogen Energy 2014;39:18135-45.

[13] Hoffmann W, Wong VW, Cheng WK, Morgenstern DA, New A. Approach to ethanol utilization: high efficiency and low $\mathrm{NO}_{\mathrm{x}}$ in an engine operating on simulated reformed ethanol. SAE Tech Pap 2008. http://dx.doi.org/10.4271/200801-2415.
[14] Tartakovsky L, Mosyak A, Zvirin Y. Energy analysis of ethanol steam reforming for internal combustion engine. Int J Energy Res 2013;37:259-67.

[15] Poran A, Artoul M, Sheintuch M, Tartakovsky L. Modeling internal combustion engine with thermo-chemical recuperation of the waste heat by methanol steam reforming. SAE Int J Engines 2014. http://dx.doi.org/10.4271/ 2014-01-1101.

[16] Chakravarthy VK, Daw CS, Pihl JA, Conklin JC. A study of the theoretical potential of thermochemical exhaust heat recuperation for internal combustion engines. Energy Fuels 2010:1529-37.

[17] Jaggi V, Jayanti S. A conceptual model of a high-efficiency, stand-alone power unit based on a fuel cell stack with an integrated auto-thermal ethanol reformer. Appl Energy 2013;110:295-303.

[18] Purnima P, Jayanti S. A high-efficiency, auto-thermal system for on-board hydrogen production for low temperature PEM fuel cells using dual reforming of ethanol. Int J Hydrogen Energy 2016;41:13800-10.

[19] Wheeler JC, Stein RA, Morgenstern DA, Sall ED, Taylor JW. Low-temperature ethanol reforming: a multi-cylinder engine demonstration. SAE Tech Pap 2011. http://dx.doi.org/10.4271/ 2011-01-0142.

[20] Sall ED, Morgenstern DA, Fornango JP, Taylor JW, Chomic N, Wheeler J. Reforming of ethanol with exhaust heat at automotive scale. Energy Fuels 2013;27:5579-88.

[21] Ji C, Dai X, Ju B, Wang S, Zhang B, Liang C, et al. Improving the performance of a spark-ignited gasoline engine with the addition of syngas produced by onboard ethanol steaming reforming. Int J Hydrogen Energy 2012;37:7860-8.

[22] Llorca J, Cortés V, Divins NJ, Olivera R, Taboada E. In: Gandía LM, Arzamendi G, Diéguez PM, editors. Hydrogen from bioethanol. Renewable hydrogen technologies. Elsevier; 2013. p. 135-69. chapter 7.

[23] Llorca J, Homs N, Sales J, Ramírez de la Piscina P. Efficient production of hydrogen over supported cobalt catalysts from ethanol steam reforming. J Catal 2002;209:306-17.

[24] Casanovas A, Roig M, de Leitenburg C, Trovarelli A, Llorca J. Ethanol steam reforming and water gas shift over $\mathrm{Co} / \mathrm{ZnO}$ catalytic honeycombs doped with $\mathrm{Fe}, \mathrm{Ni}, \mathrm{Cu}, \mathrm{Cr}$ and $\mathrm{Na}$. Int J Hydrogen Energy 2010;35:7690-8.

[25] Domínguez M, Taboada E, Idriss H, Molins E, Llorca J. Fast and efficient hydrogen generation catalyzed by cobalt talc nanolayers dispersed in silica aerogel. J Mater Chem 2010;20:4875-83.

[26] Song H, Zhang L, Ozkan US. Investigation of the reaction network in ethanol steam reforming over supported cobalt catalysts. Ind Eng Chem Res 2010;49:8984-9.

[27] Haryanto A, Fernando S, Murali N, Adhikari S. Current status of hydrogen production techniques by steam reforming of ethanol: a review. Energy Fuels 2005;19:2098-106.

[28] Idriss H, Scott M, Llorca J, Chan SC, Chiu W, Sheng PY, et al. A phenomenological study of the metal-oxide interface: the role of catalysis in hydrogen production from renewable resources. ChemSusChem 2008;1:905-10.

[29] Espinal R, Taboada E, Molins E, Chimentao RJ, Medina F, Llorca J. Cobalt hydrotalcite for the steam reforming of ethanol with scarce carbon production. RSC Adv 2012;2:2946-56.

[30] Espinal R, Taboada E, Molins E, Chimentao RJ, Medina F, Llorca J. Cobalt hydrotalcites as catalysts for bioethanol steam reforming. The promoting effect of potassium on catalyst activity and long-term stability. Appl Catal B Environ 2012;127:59-67.

[31] Espinal R, Anzola A, Adrover E, Roig M, Chimentao R, Medina F, et al. Durable ethanol steam reforming in a 
catalytic membrane reactor at moderate temperature over cobalt hydrotalcite. Int J Hydrogen Energy 2014;39:10902-10.

[32] Divins NJ, Angurell I, Escudero C, Pérez-Dieste V, Llorca J. Influence of the support on surface rearrangements of bimetallic nanoparticles in real catalysts. Science 2014;346:620-3.

[33] Divins NJ, López E, Rodríguez A, Vega D, Llorca J. Bio-ethanol steam reforming and autothermal reforming in $3-\mu \mathrm{m}$ channels coated with $\mathrm{RhPd} / \mathrm{CeO}_{2}$ for hydrogen generation. Chem Eng Process Process Intensif 2013;64:31-7.

[34] López E, Divins NJ, Llorca J. Hydrogen production from ethanol over $\mathrm{Pd}-\mathrm{Rh} / \mathrm{CeO}_{2}$ with a metallic membrane reactor. Catal Today 2012;193:145-50.

[35] Divins N, Llorca J. In situ photoelectron spectroscopy study of ethanol steam reforming over RhPd nanoparticles and RhPd/ $\mathrm{CeO}_{2}$. Appl Catal A General 2016;518:60-6.

[36] Morgenstern DA, Fornango JP. Low-temperature reforming of ethanol over copper-plated Raney nickel: a new route to sustainable hydrogen for transportation. Energy Fuels 2005;19:1708-16.

[37] Tartakovsky L, Baibikov V, Veinblat M. Comparative performance analysis of SI engine fed by ethanol and methanol reforming products. SAE Tech Pap 2013. http:// dx.doi.org/10.4271/2013-01-2617.
[38] Le Valant A, Can F, Bion N, Epron F, Duprez D. Hydrogen production from raw bioethanol steam reforming: optimization of catalyst composition with improved stability against various impurities. Int J Hydrogen Energy 2010;35:5015-20.

[39] Bion N, Duprez D, Epron F. Design of nanocatalysts for green hydrogen production from bioethanol. ChemSusChem 2012;5:76-84.

[40] De Leitenburg C, Trovarelli A, Zamar F, Maschio S, Dolcetti G, Llorca J. A novel and simple route to catalysts with a high oxygen storage capacity: the direct room-temperature synthesis of $\mathrm{CeO}_{2}-\mathrm{ZrO}_{2}$ solid solutions. J Chem Soc Chem Commun 1995:2181-2.

[41] Trovarelli A, Zamar F, de Leitenburg C, Dolcetti G, Llorca J, Kiss JT. Nanophase fluorite-structured $\mathrm{CeO}_{2}-\mathrm{ZrO}_{2}$ catalysts prepared by high-energy mechanical alloying. I: analysis of low-temperature redox activity and oxygen storage capacity. J Catal 1997;169:490-502.

[42] Song H, Ozkan U. Ethanol steam reforming over Co-based catalysts: role of oxygen mobility. J Catal 2009;261:66-74.

[43] Soler Ll, Casanovas A, Escudero C, Pérez-Dieste V, Aneggi E, Trovarelli A, et al. Ambient pressure photoemission spectroscopy reveals the mechanism of carbon soot oxidation in ceria-based catalysts. ChemCatChem 2016;8:2748-51. 